\title{
Genetic Predictors of the Development and Recurrence of Graves' Disease
}

\author{
D. VEJRAZKOVA ${ }^{1}$, J. VCELAK ${ }^{1}$, E. VACLAVIKOVA ${ }^{1}$, M. VANKOVA ${ }^{1}$, K. ZAJICKOVA $^{1}$, \\ M. DUSKOVA ${ }^{1}$, J. VRBIKOVA ${ }^{1}$, B. BENDLOVA ${ }^{1}$ \\ ${ }^{1}$ Institute of Endocrinology, Prague, Czech Republic
}

Received July 19, 2018

Accepted September 4, 2018

\section{Summary}

Graves' disease affects approximately $3 \%$ of women and $0.5 \%$ of men. The first-choice therapy is based on the administration of thyrostatic drugs. However, approximately half of patients relapse within two years of discontinuation. These patients must then decide whether to re-initiate thyrostatics, which may have serious side effects, or to undergo surgery or radioiodine treatment. Familial forms of Graves' disease indicate a significant genetic component, with twin studies demonstrating a contribution of genetic factors up to $70-80 \%$. The autoimmune nature of the disease involves the human leukocyte antigen (HLA) complex, which has a decisive impact on each individual's immune response. Within HLA, some variants of the DRB1, DQA1 and $D Q B 1$ genes appear to be possible predictors of the development and recurrence of Graves' disease. Outside the HLA region, many variants of immunocompetent genes have also been identified as potential Graves' disease predictors. Apart from the immune system, some thyroid-specific genes have been described in relation to the disease. Here, we present current knowledge regarding the genetic components involved in the development and recurrence of Graves' disease. Further, we present original pilot results from a cohort of Czech Graves' disease patients regarding the HLA variants.

\section{Key words}

Graves' disease - HLA variants • Autoimmunity • Treatment • Genetic predictors

\section{Corresponding author}

D. Vejrazkova, Department of Molecular Endocrinology, Institute of Endocrinology, Narodni 8, 11694 Prague 1, Czech Republic. Fax: +420 224905 325. E-mail: dvejrazkova@endo.cz

\section{Introduction}

Graves' disease (GD) patients produce autoantibodies against the TSH receptor, resulting in the overproduction of thyroid hormones. The disproportion in incidence of GD between women (3\%) and men $(0.5 \%)$ can largely be attributed to genetic factors and will be discussed in more detail below. The first-choice therapy is based on the administration of thyrostatic drugs for many months or even years. However, approximately half of patients relapse within two years of discontinuation. It is then necessary to decide whether to re-initiate thyrostatic treatment, which may have serious side effects in some cases (liver disorder, agranulocytosis) or to choose a more radical approach (surgical removal of the thyroid gland or radioiodine administration). Clinically well-documented familial forms of GD indicate that the disease has a significant genetic component. Studies on twin pairs have demonstrated that the contribution of genetic factors can be up to 70-80\% (Brix et al. 2001). When individuals with a susceptible genetic background are exposed to specific environmental factors like stress, smoking, excessive iodine intake, the maternal postpartum period, microbiome-induced immunological changes (Astl and Šterzl 2015), and other undiscovered conditions, production of autoantigens against the TSH receptor is triggered. The autoimmune nature of the disease involves the human leukocyte antigen (HLA) complex, the most variable genetic system in the body, which has a decisive impact on each individual's immune response. 


\section{The HLA system}

Over the past 50 years, HLA variants have been shown to significantly influence an individual's susceptibility to many autoimmune features and complex autoimmune diseases such as type 1 diabetes mellitus (Rich 2017, Kantárová and Buc 2006), multiple sclerosis (Gianfrancesco et al. 2017), systemic lupus erythematosus (Langefeld et al. 2017), myositis (Miller et al. 2018), celiac disease (Verdu and Danska 2018, Jiskra et al. 2003), psoriasis (Hirata et al. 2018), autoimmune polyglandular syndrome (Hrdá et al. 2004) and many other autoimmune disorders including autoimmune thyroid disease (AITD) (Tomer 2010). Clearly, HLA is also essential for combating infectious diseases, and its variants are involved in an individual's ability to cope with different infections (Matzaraki et al. 2017). The extreme variability of the HLA system is a consequence of long selection pressure as human populations moved around the world and faced different pathogens. The HLA complex consists of the three main regions, the classes I, II, and III. The class II molecule, which is important for a topic of this paper, is composed of $\alpha$ and $\beta$ chains, which form receptors on antigen presenting cells. These cells include macrophages, dendritic cells, endothelial cells, B-lymphocytes and other organ-specific cells. Each of the $\alpha$ and $\beta$ chains has a highly polymorphic region, together forming the antigen (more precisely epitope) binding groove. Of the HLA class II genes, some variants of the $D R B 1, D Q A 1$ and $D Q B 1$ genes appear to be possible predictors of the development and recurrence of GD. All these genes are in linkage disequilibrium, which means that they are very close to each other on the chromosome and are therefore inherited en bloc as a haplotype.

GD was initially found to be associated with allelic group DRB1*03 (Bech et al. 1977). As assessed in different Caucasian population groups around the world, the frequency of $D R B 1 * 03$ in GD patients was found to range between $40-55 \%$, but only approximately between $15-30 \%$ in the general population, giving a relative risk (RR) for $D R B 1 * 03$ carriers of up to 4 (reviewed by Tomer and Davies 2003). Later, HLA allele $D Q A 1 * 05$ was also reported to be associated with GD (Barlow et al. 1996, Yanagawa et al. 1993). Subsequently, the $D Q B 1 * 02$ gene was included and many independent case-control and family studies identified haplotype $D R B 1 * 03$ $D Q A 1 * 05-D Q B 1 * 02$ as a predictor of the development of GD with an RR of 1.9-3.8 (Gough 2000).
A recent study by Vos et al. (2016) aimed to construct a predictive model to calculate the recurrence risk after a course of antithyroid drugs. The model was based on clinical parameters (age, goiter size, fT4, and TBII - thyrotropin binding inhibiting immunoglobulins) in combination with the presence of $D R B 1 * 03, D Q A 1 * 05$, and $D Q B 1^{*} 02$ and genotyping of the $1858 \mathrm{C} / \mathrm{T}$ single nucleotide polymorphism (SNP) in the PTPN22 gene (the role of which in GD will be discussed below) prior to the start of treatment. Antithyroid drugs were withdrawn after one year, and patients were followed for a further two years. Supplementing the clinical characterization of the patients with genotyping was found to be of great value in predicting the disease recurrence and therefore also in the choice of treatment strategy.

\section{PTPN22}

One of the strongest risk factors associated with GD outside of the HLA region is the PTPN22 gene on chromosome 1p13.3-13.1 encoding for protein tyrosine phosphatase-22, a powerful inhibitor of T-cell activation. A single nucleotide polymorphism of PTPN22, rs2476601 also referred to as $1858 \mathrm{C} / \mathrm{T}$, leads to the substitution Arg620Trp, which disrupts an interaction motif in the protein (Stanford and Bottini 2014). This SNP has emerged as a major risk factor for the development of multiple autoimmune diseases including type 1 diabetes mellitus, rheumatoid arthritis, juvenile idiopathic arthritis, systemic lupus erythematosus, as well as autoimmune thyroid diseases such as Hashimoto's thyroiditis and GD (Burn et al. 2011), suggesting that aberrant activity of this phosphatase can disrupt normal lymphocyte functions. The associations are highly reproducible in many different Caucasian populations; however, in Asian and African populations the minor allele is sporadic or absent (Nabi et al. 2016). The substitution at codon 620 was found to be associated with GD exhibiting odds ratio (OR) of 1.9 in British Caucasians (Velaga et al. 2004), 1.7 in a Polish population (Skórka et al. 2005), and even 4.2 in a Russian population (Zhebrun et al. 2011) and 4.3 in a Mexican population (López-Cano et al. 2017), suggesting a marked predisposing effect to GD considering that the OR is the ratio of the odds of the disease development occurring in the group of risk allele carriers to the odds of it occurring in the group of risk allele non-carriers. 


\section{Pilot results in Czech patients}

The aim of our work in the Institute of Endocrinology in Prague was to verify the predictive potential of the model assessed on the Dutch population by Vos et al. (2016) in Czech GD patients who have undergone treatment and are continuously monitored in our Institute. We have classified the HLA-DRB1, HLA-DQA1 and HLA-DQB1 allelic groups as well as the PTPN22 polymorphism rs2476601 in first 50 patients. The new generation sequencing performed on MiSeq (Illumina, San Diego, California, USA) was chosen as the most reliable haplotyping method. In our cohort, $40 \%$ of the patients carried the $D R B 1 * 03-D Q A 1 * 05-D Q B 1 * 02$ haplotype, which confirms the findings of the abovementioned meta- analysis (reviewed by Gough 2000) and complements that information with Czech data. For some HLA allelic groups, the Allele Frequencies website (http://www.allelefrequencies.net/) allowed a comparison of our results from GD patients with the Czech bone marrow donors $(\mathrm{n}=5,099)$ : the $D R B 1 * 03$ allele was more frequent in the GD group (23\%) compared with bone marrow donors $(12 \%)$, which is in agreement with previous findings in other populations (Tomer and Davies 2003). On the contrary, the $D R B 1^{*} 07$ allele was less frequent in our GD group ( $4 \%$ ) in comparison with bone marrow donors $(14 \%)$. The DRB $1 * 07$ allele has been reported to be protective for GD in UK Caucasians (Simmonds et al. 2005); however, a larger cohort of patients is necessary to assess its protective role in the Czech population. Concerning the patients whose disease had recurred $(n=24)$, the eight hypothetically possible predisposing allelic variants (i.e. $D R B 1 * 03, D Q A 1 * 05$, $D Q B 1^{*} 02$, and PTPN22 rs2476601 variant, each from one or both parents) were distributed as follows: no risk allele in four individuals (16.7\%), one risk allele in six individuals $(25 \%)$, two risk alleles in two individuals $(8.3 \%)$, three risk alleles in six individuals $(25 \%)$, four risk alleles in five individuals $(20.8 \%)$, and five risk alleles in one individual (4.2\%). Unfortunately, there were only two patients who had not yet relapsed and whose remission had lasted for more than two years: one was carrying no risk allele and the other was carrying two risk alleles. Such a disproportion in the size of the groups to be compared limits us regarding statistical evaluations. Nevertheless, Fisher's exact test identified allelic group $D Q A 1^{*} 05$ to be close to statistical significance in terms of the ability to predict the recurrence $(\mathrm{p}=0.06)$. In other words, there was no $D Q A I^{*} 05$ carrier among the successfully treated patients, while there were 19 out of $24 D Q A 1 * 05$ carriers ( $80 \%$ ) among the unsuccessfully treated patients. The remaining patients from the current cohort could not yet be included in the statistical analysis as they were still being treated or their remission period had not yet lasted two years (Vejrazkova et al. 2018).

\section{Other immunocompetent genes outside the HLA region}

\section{CTLA-4}

The cytotoxic $\mathrm{T}$ lymphocyte antigen 4 gene (CTLA-4) encodes a vital regulatory molecule of the immune system that participates in the presentation of antigenic peptides to T-cells. Several polymorphisms in this gene may decrease its expression or function (Ueda et al. 2003), thereby promoting the development of autoimmunity, including autoimmune thyroid diseases. Numerous case-control studies have shown an association between GD susceptibility and different $C T L A-4$ SNPs or microsatellite markers with an OR of approximately 2-3 (Tomer and Davies 2003, Fouad et al. 2017). Major findings resulted from the study conducted by Kim et al. (2007), which suggested that genetic markers associated with the development of the disease cannot always be used to predict the disease relapse. Although strongly associated with the development of GD, CTLA-4 is not associated with the occurrence of relapse after antithyroid withdrawal. This was also true of the CD40 gene (see below).

\section{CD40}

The cluster of differentiation 40 (CD40) plays a fundamental role in the cross-talk between antigen presenting cells and T-cells and is essential for B cell activation, providing a crucial signal for their proliferation, differentiation, and immunoglobulin production. As a strong humoral component the gene has been shown to be relevant in autoimmune diseases like rheumatoid arthritis, systemic lupus erythematosus, and multiple sclerosis (van der Linden et al. 2009, Gaffney et al. 2006, Australia and New Zealand Multiple Sclerosis Genetics Consortium 2009). Already in 1996, CD40 was postulated to be linked with susceptibility to GD in mice (Resetkova et al. 1996). These findings have been replicated in humans, regardless of ethnicity (Jacobson et al. 2005, reviewed by Jacobson and Tomer 2007). However, as said above, variants in the CD40 gene cannot predict the recurrence of GD (Kim et al. 2007). 


\section{FOXP3}

FOXP3, located on the $\mathrm{X}$ chromosome, encodes a forkhead/winged helix transcription factor that is a critical determinant of $\mathrm{T}$ regulatory cell development and function. Mutations in this gene result in severe immunodysregulation, polyendocrinopathy, and enteropathy - a serious X-linked disability known as IPEX syndrome. Polymorphisms in FOXP3 and its promoter have been associated with the risk of developing GD with an OR $>5$ in some populations (Ban et al. 2007, Bossowski et al. 2014, Shehjar et al. 2018). One study found that the association of FOXP3 with GD was mostly in the subset of patients with the juvenile form of the disease (Tomer et al. 2007).

\section{ARID5B}

The ARID5B gene encodes for AT-rich interaction domain $5 \mathrm{~B}$, which is a DNA binding protein that regulates the transcription of target genes involved in adipogenesis and liver development. This gene also plays a role in the differentiation of B-lymphocyte progenitors, and it is therefore believed to be a general autoimmunity gene. A meta-analysis of GWAS reported a significant association of the gene with rheumatoid arthritis and AITD, including both Hashimoto's thyroiditis and Graves' disease (Okada et al. 2012, Tomer et al. 2013).

\section{$N R X N 3$}

$N R X N 3$, or neurexin 3, is a neuronal cell surface protein that functions as a cell adhesion molecule and is thought to be involved in synaptic plasticity. Polymorphisms in NRXN3 have been linked to genetic predispositions to a number of conditions such as alcohol and drug addictions, obesity, and thyroid autoimmunity with an $\mathrm{OR}=2.3$ for GD (Tomer et al. 2013).

\section{IKZF3}

The IKZF3 gene encodes a zinc-finger protein that plays an important role in the proliferation and differentiation of B-lymphocytes. Recently, an association between five SNPs in this gene and GD was reported, with an OR in the range of 1.3-2.0 (Li et al. 2018). Furthermore, the study suggested that $I K Z F 3$ is probably not the susceptible gene for Hashimoto's thyroiditis, since no locus resulted in a statistical difference between patients and controls. It seems clear that even though Graves' disease and Hashimoto's thyroiditis share a similar pathogenetic mechanism in which autoreactive T-cells escape tolerance and infiltrate the thyroid gland, genetic factors playing roles in their etiology may be different.

\section{Thyroid-specific genes}

Polymorphisms in the thyroglobulin gene and variants in TSHR gene have also been found to be associated with GD pathogenesis (Tomer et al. 2002, Hsiao et al. 2008, Fujii et al. 2017).

\section{Thyroglobulin}

A whole-genome linkage study identified the thyroglobulin gene as a major AITD susceptible gene (Tomer et al. 2003), and was replicated in various ethnic groups. Further, a possible genetic interaction has been described between one of the thyroglobulin variants and the HLA DRB1 gene conferring a high susceptibility to GD (Hodge et al. 2006).

\section{TSHR}

As TSHR is the main target of the immune response in GD, the gene for the receptor was, along with the HLA genes, among the first to be tested for an association with GD. Associations were found in several intronic regions, with the most consistent variants in Caucasians being found in intron 1, altering the transcription and splicing of the gene (Stefan and Faustino 2017). The variant rs2268458 was associated with GD (OR 1.7-1.8), but not with autoimmune hypothyroidism, indicating that this TSHR region represents a GD-specific locus (Dechairo et al. 2005, Yin et al. 2008).

\section{The gender issue - the influence of two $\mathrm{X}$ chromosomes and parity}

GD is 5-10 times more frequent in women. This may be to some extent explained by estrogenic sex steroids in promoting autoimmunity (Grossman et al. 1991), but this does not explain the observed female preponderance of GD in early childhood. Genetic factors were already mentioned in connection with the X-linked gene FOXP3. However, there are additional immune regulatory genetic factors such as the $C D 40$ ligand gene and others located on the X chromosome: therefore, females with two $\mathrm{X}$ chromosomes are twice as likely to inherit susceptible X-linked regulatory elements. Furthermore, X chromosome inactivation during early embryonic development is a major regulatory feature in 
which one $\mathrm{X}$ chromosome of each female embryo cell is transcriptionally silenced. Inactivation is a random process, so sometimes skewed inactivation occurs when one $\mathrm{X}$ chromosome is silenced proportionately more often than the other one. This imbalance has been proposed as a potential mechanism explaining the female preponderance of GD. In the case of significantly skewed inactivation, the immune repertoire will not entirely tolerate the minor version of the two self-antigens encoded by the two X chromosomes. Lymphocytes could then be autoreactive to those minor X-linked antigens and induce an autoimmune process (Simmonds et al. 2014).

Another exclusively female issue that can induce the development of autoimmune processes is the postpartum period. During pregnancy, fetal cells are known to reach maternal circulation and infiltrate a variety of tissues including the thyroid gland (Ando et al. 2002). This condition, known as fetal microchimerism, can persist for more than 20 years after the childbirth. Fetal cells, representing semi-alloantigens for the mother, may provoke the immune system and trigger autoreactivity. To make things more complicated, there is another circumstance that may pose a threat during the postpartum period. In pregnant women, the immune system is suppressed to protect the fetus, but in the first postpartum months its activation occurs and, in predisposed women, thyroid autoantibody production may rise (Draca 2002).

\section{Conclusion}

Studies in the past two decades have demonstrated that multiple factors are involved in the development and recurrence of GD. The interaction of environmental factors with susceptible genes may have synergistic effects in breaking the immunological tolerance and trigger the disease. This interaction is mediated through dynamic epigenetic modulation (Wang et al. 2017, Imgenberg-Kreuz et al. 2018). Epigenetic modifications caused by an inconstant environment may drive genetically predisposed individuals to develop the disease. In addition to HLA variants, many non-HLA genes have been confirmed as being susceptibility genes contributing to the etiology of GD, some are unique to the recurrence of GD, while others are common to both the disease development and recurrence. Others pose a risk for the development of AITD in general or even a wider range of autoimmune diseases. The current unprecedented progress in genetics is increasingly identifying genetic variants for which the mechanisms of influence on the development of autoimmune diseases are better understood (Tomer 2014). Support for research is the only way to advance the mechanism-based therapy of autoimmune diseases, personalized choice of treatment approaches and more accurate predictions of treatment outcomes.

\section{Conflict of Interest}

There is no conflict of interest.

\section{Acknowledgements}

The authors would like to thank Mgr. Nela Vondrková and Zuzana Chroustová for their excellent assistance. Thanks also to all physicians of the Institute of Endocrinology who send patients for genetic testing. Grant support: MH CZ - DRO (Institute of Endocrinology - EÚ, 00023761).

\section{Abbreviations}

AITD - autoimmune thyroid disease, ARID5B - AT-rich interaction domain 5B, CD40 - cluster of differentiation 40, CTLA-4 - cytotoxic T lymphocyte antigen 4 gene, FOXP3 - forkhead box P3, GD - Graves' disease, HLA human leukocyte antigen, IKZF3 - Ikaros family zinc finger protein 3, NRXN3 - neurexin 3, OR - odds ratio, PTPN22 - protein tyrosine phosphatase-22, RR - relative risk, SNP - single nucleotide polymorphism, TBII thyrotropin binding inhibiting immunoglobulins, TSH thyroid-stimulating hormone, TSHR - receptor for thyroid-stimulating hormone.

\section{References}

ANDO T, IMAIZUMI M, GRAVES PN, UNGER P, DAVIES TF: Intrathyroidal fetal microchimerism in Graves' disease. J Clin Endocrinol Metab 87: 3315-3320, 2002.

ASTL J, ŠTERZL I: Activation of Helicobacter pylori causes either autoimmune thyroid diseases or carcinogenesis in the digestive tract. Physiol Res 64 (Suppl 2): S291-S301, 2015. 
AUSTRALIA AND NEW ZEALAND MULTIPLE SCLEROSIS GENETICS CONSORTIUM (ANZGENE): Genomewide association study identifies new multiple sclerosis susceptibility loci on chromosomes 12 and 20. Nat Genet 41: 824-828, 2009.

BAN Y, TOZAKI T, TOBE T, BAN Y, JACOBSON EM, CONCEPCION ES, TOMER Y: The regulatory T cell gene FOXP3 and genetic susceptibility to thyroid autoimmunity: an association analysis in Caucasian and Japanese cohorts. J Autoimmun 28: 201-207, 2007.

BARLOW AB, WHEATCROFT N, WATSON P, WEETMAN AP: Association of HLA-DQA1*0501 with Graves' disease in English Caucasian men and women. Clin Endocrinol (Oxf) 44: 73-77, 1996.

BECH K, LUMHOLTZ B, NERUP J, THOMSEN M, PLATZ P, RYDER LP, SVEJGAARD A, SIERSBAEKNIELSEN K, HANSEN JM, LARSEN JH: HLA antigens in Graves' disease. Acta Endocrinol (Copenh) 86: 510-516, 1977.

BOSSOWSKI A, BORYSEWICZ-SAŃCZYK H, WAWRUSIEWICZ-KURYLONEK N, ZASIM A, SZALECKI M, WIKIERA B, BARG E, MYŚLIWIEC M, KUCHARSKA A, BOSSOWSKA A, GOŚCIK J, ZIORA K, GÓRSKA M, KRĘTOWSKI A: Analysis of chosen polymorphisms in FoxP3 gene in children and adolescents with autoimmune thyroid diseases. Autoimmunity 47: 395-400, 2014.

BRIX TH, KYVIK KO, CHRISTENSEN K, HEGEDÜS L: Evidence for a major role of heredity in Graves' disease: a population-based study of two Danish twin cohorts. J Clin Endocrinol Metab 86: 930-934, 2001.

BURN GL, SVENSSON L, SANCHEZ-BLANCO C, SAINI M, COPE AP: Why is PTPN22 a good candidate susceptibility gene for autoimmune disease? FEBS Lett 585: 3689-3698, 2011.

DECHAIRO BM, ZABANEH D, COLLINS J, BRAND O, DAWSON GJ, GREEN AP, MACKAY I, FRANKLYN JA, CONNELL JM, WASS JA, WIERSINGA WM, HEGEDUS L, BRIX T, ROBINSON BG, HUNT PJ, WEETMAN AP, CAREY AH, GOUGH SC: Association of the TSHR gene with Graves' disease: the first disease specific locus. Eur J Hum Genet 13: 1223-1230, 2005.

DRACA S: Is pregnancy a model how we should control some autoimmune diseases? Autoimmunity 35: 307-312, 2002.

FOUAD NA, SAEED AM, MAHEDY AW: Association of CTLA-4 +49 A/G and CT60 gene polymorphism with Graves' disease. Egypt J Immunol 24: 63-70, 2017.

FUJII A, INOUE N, WATANABE M, KAWAKAMI C, HIDAKA Y, HAYASHIZAKI Y, IWATANI Y: TSHR gene polymorphisms in the enhancer regions are most strongly associated with the development of Graves' disease, especially intractable disease, and of Hashimoto's disease. Thyroid 27: 111-119, 2017.

GAFFNEY PM, LANGEFELD CD, GRAHAM RR, ORTMANN WA, WILLIAMS AH, RODINE PR, MOSER KL, BEHRENS TW: Fine-mapping chromosome 20 in 230 systemic lupus erythematosus sib pair and multiplex families: evidence for genetic epistasis with chromosome 16q12. Am J Hum Genet 78: 747-758, 2006.

GIANFRANCESCO MA, STRIDH P, SHAO X, RHEAD B, GRAVES JS, CHITNIS T, WALDMAN A, LOTZE T, SCHREINER T, BELMAN A, GREENBERG B, WEINSTOCK-GUTTMAN B, AAEN G, TILLEMA JM, HART J, CAILLIER S, NESS J, HARRIS Y, RUBIN J, CANDEE M, KRUPP L, GORMAN M, BENSON L, RODRIGUEZ M, MAR S, KAHN I, ROSE J, ROALSTAD S, CASPER TC, SHEN L, QUACH H, QUACH D, HILLERT J, HEDSTROM A, OLSSON T, KOCKUM I, ALFREDSSON L, SCHAEFER C, BARCELLOS LF, WAUBANT E; NETWORK OF PEDIATRIC MULTIPLE SCLEROSIS CENTERS: Genetic risk factors for pediatric-onset multiple sclerosis. Mult Scler: $1352458517733551,2017$.

GOUGH SC: The genetics of Graves' disease. Endocrinol Metab Clin North Am 29: 255-266, 2000.

GROSSMAN CJ, ROSELLE GA, MENDENHALL CL: Sex steroid regulation of autoimmunity. J Steroid Biochem Mol Biol 40: 649-659, 1991.

HIRATA J, HIROTA T, OZEKI T, KANAI M, SUDO T, TANAKA T, HIZAWA N, NAKAGAWA H, SATO S, MUSHIRODA T, SAEKI H, TAMARI M, OKADA Y: Variants at HLA-A, HLA-C, and HLA-DQB1 confer risk of psoriasis vulgaris in Japanese. J Invest Dermatol 138: 542-548, 2018.

HODGE SE, BAN Y, STRUG LJ, GREENBERG DA, DAVIES TF, CONCEPCION ES, VILLANUEVA R, TOMER Y: Possible interaction between HLA-DRbetal and thyroglobulin variants in Graves' disease. Thyroid 16: 351-355, 2006.

HRDÁ P, STERZL I, MATUCHA P, KORIOTH F, KROMMINGA A: HLA antigen expression in autoimmune endocrinopathies. Physiol Res 53: 191-197, 2004. 
HSIAO JY, HSIEH MC, TIEN KJ, HSU SC, LIN SR, KE DS: Exon 33 T/T genotype of the thyroglobulin gene is a susceptibility gene for Graves' disease in Taiwanese and exon $12 \mathrm{C} / \mathrm{C}$ genotype protects against it. Clin Exp Med 8: 17-21, 2008.

IMGENBERG-KREUZ J, CARLSSON ALMLÖF J, LEONARD D, ALEXSSON A, NORDMARK G, ELORANTA ML, RANTAPÄÄ-DAHLQVIST S, BENGTSSON AA, JÖNSEN A, PADYUKOV L, GUNNARSSON I, SVENUNGSSON E, SJÖWALL C, RÖNNBLOM L, SYVÄNEN AC, SANDLING JK: DNA methylation mapping identifies gene regulatory effects in patients with systemic lupus erythematosus. Ann Rheum Dis 77: 736-743, 2018.

JACOBSON EM, CONCEPCION E, OASHI T, TOMER Y: A Graves' disease-associated Kozak sequence singlenucleotide polymorphism enhances the efficiency of CD40 gene translation: a case for translational pathophysiology. Endocrinology 146: 2684-2691, 2005.

JACOBSON EM, TOMER Y: The CD40, CTLA-4, thyroglobulin, TSH receptor, and PTPN22 gene quintet and its contribution to thyroid autoimmunity: back to the future. J Autoimmun 28: 85-98, 2007.

JISKRA J, LÍMANOVÁ Z, VANÍCKOVÁ Z, KOCNA P: IgA and IgG antigliadin, IgA anti-tissue transglutaminase and antiendomysial antibodies in patients with autoimmune thyroid diseases and their relationship to thyroidal replacement therapy. Physiol Res 52: 79-88, 2003.

KANTÁROVÁ D, BUC M: Genetic susceptibility to type 1 diabetes mellitus in humans. Physiol Res 56: 255-266, 2007.

KIM KW, PARK YJ, KIM TY, PARK DJ, PARK KS, CHO BY: Susceptible alleles of the CD40 and CTLA-4 genes are not associated with the relapse after antithyroid withdrawal in Graves' disease. Thyroid 17: 1229-1234, 2007.

LANGEFELD CD, AINSWORTH HC, CUNNINGHAME GRAHAM DS, KELLY JA, COMEAU ME, MARION MC, HOWARD TD, RAMOS PS, CROKER JA, MORRIS DL, SANDLING JK, ALMLÖF JC, ACEVEDOVÁSQUEZ EM, ALARCÓN GS, BABINI AM, BACA V, BENGTSSON AA, BERBOTTO GA, BIJL M, BROWN EE, ET AL.: Transancestral mapping and genetic load in systemic lupus erythematosus. Nat Commun 8: 16021, 2017.

LI L, DING X, WANG X, YAO Q, SHAO X, AN X, YAN N, JIANG Y, WANG W, SHI L, QIN Q, SONG R, ZHANG JA, SUN P: Polymorphisms of IKZF3 gene and autoimmune thyroid diseases: associated with Graves' disease but not with Hashimoto's thyroiditis. Cell Physiol Biochem 45: 1787-1796, 2018.

LÓPEZ-CANO DJ, CADENA-SANDOVAL D, BELTRÁN-RAMÍREZ O, BARBOSA-COBOS RE, SÁNCHEZMUÑOZ F, AMEZCUA-GUERRA LM, JUÁREZ-VICUÑA Y, AGUILERA-CARTAS MC, MORENO J, BAUTISTA-OLVERA J, VALENCIA-PACHECO G, LÓPEZ-VILLANUEVA RF, RAMÍREZ-BELLO J: The PTPN22 R263Q polymorphism confers protection against systemic lupus erythematosus and rheumatoid arthritis, while PTPN22 R620W confers susceptibility to Graves' disease in a Mexican population. Inflamm Res 66: 775-781, 2017.

MATZARAKI V, KUMAR V, WIJMENGA C, ZHERNAKOVA A: The MHC locus and genetic susceptibility to autoimmune and infectious diseases. Genome Biol 18: 76, 2017.

MILLER FW, LAMB JA, SCHMIDT J, NAGARAJU K: Risk factors and disease mechanisms in myositis. Nat Rev Rheumatol 14: 255-268, 2018.

NABI G, AKHTER N, WAHID M, BHATIA K, MANDAL RK, DAR SA, JAWED A, HAQUE S: Meta-analysis reveals PTPN22 1858C/T polymorphism confers susceptibility to rheumatoid arthritis in Caucasian but not in Asian population. Autoimmunity 49: 197-210, 2016.

OKADA Y, TERAO C, IKARI K, KOCHI Y, OHMURA K, SUZUKI A, KAWAGUCHI T, STAHL EA, KURREEMAN FA, NISHIDA N, OHMIYA H, MYOUZEN K, TAKAHASHI M, SAWADA T, NISHIOKA Y, YUKIOKA M, MATSUBARA T, WAKITANI S, TESHIMA R, TOHMA S, ET AL.: Meta-analysis identifies nine new loci associated with rheumatoid arthritis in the Japanese population. Nat Genet 44: 511-516, 2012.

RESETKOVA E, KAWAI K, ENOMOTO T, ARREAZA G, TOGUN R, FOY TM, NOELLE RJ, VOLPÉ R: Antibody to gp39, the ligand for CD40 significantly inhibits the humoral response from Graves' thyroid tissues xenografted into severe combined immunodeficient (SCID) mice. Thyroid 6: 267-273, 1996. 
RICH SS: Genetics and its potential to improve type 1 diabetes care. Curr Opin Endocrinol Diabetes Obes 24: 279-284, 2017.

SHEHJAR F, AFROZE D, MISGAR RA, MALIK SA, LAWAY BA: Association of FoxP3 promoter polymorphisms with the risk of Graves' disease in ethnic Kashmiri population. Gene 672: 88-92, 2018.

SIMMONDS MJ, HOWSON JM, HEWARD JM, CORDELL HJ, FOXALL H, CARR-SMITH J, GIBSON SM, WALKER N, TOMER Y, FRANKLYN JA, TODD JA, GOUGH SC: Regression mapping of association between the human leukocyte antigen region and Graves' disease. Am J Hum Genet 76: 157-163, 2005.

SIMMONDS MJ, KAVVOURA FK, BRAND OJ, NEWBY PR, JACKSON LE, HARGREAVES CE, FRANKLYN JA, GOUGH SC: Skewed X chromosome inactivation and female preponderance in autoimmune thyroid disease: an association study and meta-analysis. J Clin Endocrinol Metab 99: E127-E131, 2014.

SKÓRKA A, BEDNARCZUK T, BAR-ANDZIAK E, NAUMAN J, PLOSKI R: Lymphoid tyrosine phosphatase (PTPN22/LYP) variant and Graves' disease in a Polish population: association and gene dose-dependent correlation with age of onset. Clin Endocrinol (Oxf) 62: 679-682, 2005.

STANFORD SM, BOTTINI N: PTPN22: the archetypal non-HLA autoimmunity gene. Nat Rev Rheumatol 10: 602-611, 2014.

STEFAN M, FAUSTINO LC: Genetics of thyroid-stimulating hormone receptor-relevance for autoimmune thyroid disease. Front Endocrinol (Lausanne) 8: 57, 2017.

THE ALLELE FREQUENCIES WEBSITE: http://www.allelefrequencies.net/

TOMER Y: Genetic susceptibility to autoimmune thyroid disease: past, present, and future. Thyroid 20: 715-725, 2010.

TOMER Y: Mechanisms of autoimmune thyroid diseases: from genetics to epigenetics. Annu Rev Pathol 9: 147-156, 2014.

TOMER Y, DAVIES TF: Searching for the autoimmune thyroid disease susceptibility genes: from gene mapping to gene function. Endocr Rev 24: 694-717, 2003.

TOMER Y, GREENBERG DA, CONCEPCION E, BAN Y, DAVIES TF: Thyroglobulin is a thyroid specific gene for the familial autoimmune thyroid diseases. $J$ Clin Endocrinol Metab 87: 404-407, 2002.

TOMER Y, BAN Y, CONCEPCION E, BARBESINO G, VILLANUEVA R, GREENBERG DA, DAVIES TF: Common and unique susceptibility loci in Graves and Hashimoto diseases: results of whole-genome screening in a data set of 102 multiplex families. Am J Hum Genet 73: 736-747, 2003.

TOMER Y, MENCONI F, DAVIES TF, BARBESINO G, ROCCHI R, PINCHERA A, CONCEPCION E, GREENBERG DA: Dissecting genetic heterogeneity in autoimmune thyroid diseases by subset analysis. J Autoimmun 29: 69-77, 2007.

TOMER Y, HASHAM A, DAVIES TF, STEFAN M, CONCEPCION E, KEDDACHE M, GREENBERG DA: Fine mapping of loci linked to autoimmune thyroid disease identifies novel susceptibility genes. $J$ Clin Endocrinol Metab 98: E144-E152, 2013.

UEDA H, HOWSON JM, ESPOSITO L, HEWARD J, SNOOK H, CHAMBERLAIN G, RAINBOW DB, HUNTER KM, SMITH AN, DI GENOVA G, HERR MH, DAHLMAN I, PAYNE F, SMYTH D, LOWE C, TWELLS RC, HOWLETT S, HEALY B, NUTLAND S, RANCE HE, ET AL.: Association of the T-cell regulatory gene CTLA4 with susceptibility to autoimmune disease. Nature 423: 506-511, 2003.

VAN DER LINDEN MP, FEITSMA AL, LE CESSIE S, KERN M, OLSSON LM, RAYCHAUDHURI S, BEGOVICH AB, CHANG M, CATANESE JJ, KURREEMAN FA, VAN NIES J, VAN DER HEIJDE DM, GREGERSEN PK, HUIZINGA TW, TOES RE, VAN DER HELM-VAN MIL AH: Association of a single-nucleotide polymorphism in CD40 with the rate of joint destruction in rheumatoid arthritis. Arthritis Rheum 60: 2242-2247, 2009.

VEJRAZKOVA D, VCELAK J, VACLAVIKOVA E, VANKOVA M, LUKASOVA P, BENDLOVA B: Predictive value of HLA variants for Graves' disease recurrence - pilot study in Czech patients. Endocrine Abstracts 56: P1043, 2018.

VELAGA MR, WILSON V, JENNINGS CE, OWEN CJ, HERINGTON S, DONALDSON PT, BALL SG, JAMES RA, QUINTON R, PERROS P, PEARCE SH: The codon 620 tryptophan allele of the lymphoid tyrosine phosphatase (LYP) gene is a major determinant of Graves' disease. J Clin Endocrinol Metab 89: 5862-5865, 2004. 
VERDU EF, DANSKA JS: Common ground: shared risk factors for type 1 diabetes and celiac disease. Nat Immunol 19: 685-695, 2018.

VOS XG, ENDERT E, ZWINDERMAN AH, TIJSSEN JG, WIERSINGA WM: Predicting the risk of recurrence before the start of antithyroid drug therapy in patients with Graves' hyperthyroidism. J Clin Endocrinol Metab 101: 1381-1389, 2016.

WANG B, SHAO X, SONG R, XU D, ZHANG JA: The emerging role of epigenetics in autoimmune thyroid diseases. Front Immunol 8: 396, 2017.

YANAGAWA T, MANGKLABRUKS A, CHANG YB, OKAMOTO Y, FISFALEN ME, CURRAN PG, DEGROOT LJ: Human histocompatibility leukocyte antigen-DQA $1 * 0501$ allele associated with genetic susceptibility to Graves' disease in a Caucasian population. J Clin Endocrinol Metab 76: 1569-1574, 1993.

YIN X, LATIF R, BAHN R, TOMER Y, DAVIES TF: Influence of the TSH receptor gene on susceptibility to Graves' disease and Graves' ophthalmopathy. Thyroid 18: 1201-1206, 2008.

ZHEBRUN D, KUDRYASHOVA Y, BABENKO A, MASLYANSKY A, KUNITSKAYA N, POPCOVA D, KLUSHINA A, GRINEVA E, KOSTAREVA A, SHLYAKHTO E: Association of PTPN22 1858T/T genotype with type 1 diabetes, Graves' disease but not with rheumatoid arthritis in Russian population. Aging (Albany NY) 3: 368-373, 2011. 